\title{
Modification of District Integrated Administrative Services (PATEN) and Super Service Delivery Models at Polewali Mandar
}

\author{
Sitti Chaeriah Ahsan ${ }^{1}$, Risma Niswaty, Irsyad Dhahri \\ Universitas Tadulako (email: risma.niswaty@unm.ac.id)
}

\begin{abstract}
In order to realize the demands of the community in service, the government will seek several things to improve the quality of services provided by bringing up a policy. To produce a quality policy requires good cooperation by the local government. Improving public services to optimize services in the regions can be done by reforming the administration at a level that is directly dealing with the community, namely at the sub-district level and implementing innovation. The innovation in question is the sub-district integrated administrative service system (PATEN). PATEN is held with the aim of realizing the sub-district as a community service center and becoming a service node for the one-stop integrated service agency/office (PTSP) in the district for sub-districts whose geographical area will be more effectively and efficiently served through the sub-district. With a qualitative method, this research on the implementation of PATEN in Polewali Mandar was studied based on the concepts of communication, resources, disposition, and bureaucratic structure. Obstacles encountered in communication due to limitations in providing patent services to the public during the covid 19 pandemic, PATEN service providers were provided with training, related to disposition, clearer supervision standards were needed regarding the use and supervision of budgets by districts so that achievements and obstacles could be evaluated on a regular basis ; and simplification of standard operating procedures on aspects of bureaucratic structure.
\end{abstract}

\section{Keywords:}

Implementation; policy; paten; sub-district level

\section{Introduction}

As a consequence of the implementation of Regional Autonomy, especially after the enactment of Law Number 23 of 2014 (President, 2015) concerning Regional Government, in which the Regional Government is given such broad authority by the Central Government to regulate its own regional household, including the provision of services. to the community in the area. Public service is a form of service provided by the government/bureaucrats to the community in meeting the necessary needs. Public services referred to in Kemenpan Number 63 of 2003 (Ministry of Administrative Reform of the Republic of Indonesia, 2003) are all public 
service activities as an effort to fulfill the needs of service recipients as well as the implementation of statutory regulations. The community will have more demands to get optimal service for the satisfaction of services received from the organizers.

In order to realize the demands of the community in service, the government will seek several things to improve the quality of services provided by bringing up a policy. To produce a quality policy requires good cooperation by the local government. One of them is to improve the quality and bring services closer to the community in the region, it is necessary to optimize sub-district services as the leading regional apparatus in providing public services. The quality of public services in the regions still needs to be improved in a better direction. Improving public services to optimize services in the regions can be done by reforming the administration at a level that directly deals with the community, namely at the sub-district level. Traditionally, administrative reform has been identified with efforts to improve organizational efficiency and effectiveness. In a narrow sense, the goal of administrative reform is to improve administration, or in the term (Caiden, 1991) to treat maladministrative.

In accordance with the regional autonomy policy paradigm (based on Law Number 32 of 2004 followed by Law Number 23 of 2014) concerning Regional Government, it has been explicitly mandated that to improve people's welfare, it will be pursued through 3 channels, namely: improving public services, increasing community participation and empowerment and increasing competitiveness. But here what is more dominant is the improvement of public services so that it appears that public services have a very important role as one of the general tasks of the government in addition to regulation and empowerment (Law No. 23 of 2014 concerning regional government, 2014). Because improving public services has changed the main tasks of local governments from being development promoters to public servants, so that government units that deal with and provide direct services to the community need to be prioritized, including services at the sub-district level.

The underlying thing related to service improvement in sub-districts is strengthened by Government Regulation No. 19 of 2008 concerning sub-districts which is a reference for increasing the contribution of the Camat and sub-district apparatus in carrying out their duties optimally. The issuance of this regulation explains that the sub-district has an important meaning in local government and the implementation of autonomy (Government, 2008). The government is expected to innovate to improve its performance. In this context, 
innovation is intended as an effort to improve public services provided through new approaches, methods, or tools in public services. The innovation in question is the sub-district integrated administrative service system (PATEN).

Strengthened by the policy of the Minister of Home Affairs:

1. Minister of Home Affairs Regulation No. 4 of 2010 concerning guidelines for integrated subdistrict administration services (PATEN) (Menpan, 2010).

"Article 1 paragraph 4 which reads District Integrated Administrative Services, hereinafter abbreviated as PATEN, is the implementation of public services in the sub-district from the application stage to the issuance stage of documents in one place"

2. Decree of the Minister of Home Affairs No. 138-270 of 2010 concerning Technical Guidelines for Sub-District Integrated Administration Services (PATEN) (Kepmdagri, 2017).

3. Regulation of the Regent of Polewali Mandar Number 10 of 2013 concerning Job Descriptions for Implementing Integrated District Administrative Services within the Polewali Mandar Regency Government (Perbub No 10, 2013)

PATEN here is a macro policy because it comes from the center so that it can be applied thoroughly in the region in Indonesia. District Integrated Administrative Services (PATEN) to facilitate and bring the government closer to the community, especially in public services. With PATEN, to take care of small-scale licensing and non-licensing services, people no longer need to go to the Regency Office because PATEN can save time and cost in fulfilling the services desired by the community.

Polewali Mandar Regency has 17 sub-districts, 4 (four) of the 17 (seventeen) subdistricts are Polewali District, Wonomulyo District, Campalagian District and Tinambung District which have implemented the District Integrated Administrative Service (PATEN) and has been implemented since 2013 as stated in "Polewali Mandar Regent Decree Number: KTSP/138/51/HUK (Polewali Mandar Regent Decree, 2013) regarding the determination of Polewali District, Wonomulyo District, Campalagian District and Tinambung District as the organizer of integrated sub-district administrative services within the Polewali Mandar district in 2013.

District Integrated Administrative Service (PATEN) is the implementation of public services in the sub-district whose management process, starting from the application to the 
issuance stage of the document, is carried out in one place. This one place here means enough to go through one table or service counter. This PATEN system positions the community members to only relate to the service desk/counter staff in the sub-district. The District Integrated Administrative Service (PATEN) is held with the aim of realizing the sub-district as a community service center and becoming a service node for the one-stop integrated service agency/office (PTSP) in the district for sub-districts whose geographical area will be more effectively and efficiently served through the sub-district. The community service center means that in the future, the sub-district must be able to provide services to the community proportionally based on the criteria and the sub-district scale in the field of licensing and nonlicensing. This improvement in service quality is mainly seen from the aspect of time and service costs.

Through the implementation of PATEN, citizens can receive faster and measurable services that are clearly faster than before the existence of PATEN. If previously to take care of a type of letter or recommendation, a resident who came to the sub-district office had to wait for the completion of the letter/recommendation, it could be within an hour, a few hours to several days, because the Camat or the authorized officer was not in place, then through PATEN, Citizens are guaranteed to receive fast and clearly measurable services in accordance with service standards. In the service operational standard, it is stated that the completion time of one type of public service has been determined, whether it is 15 minutes, 30 minutes or 1 hour, the required documents to be completed, the officer serving and the service fee (if any). If the authorized officer is not in place, his duties are delegated to another appointed officer, so that services to the community can still be guaranteed.

According to George Edward III. In the public policy cycle, policy implementation is a very important stage. Implementation is often considered only the implementation of what has been decided by the legislature or decision makers, as if this stage has less effect. However, in reality, the implementation stage is very important because a policy will mean nothing if it cannot be implemented properly and correctly. In other words, implementation is the stage where a policy is implemented optimally and can achieve the policy objectives themselves. In addition, Robert Nakamura and Frank Smallwood in Winarno (2004:201) matters relating to policy implementation are success in evaluating problems and then translating into specific decisions. 
A policy implementation involving many organizations and levels of bureaucracy can be viewed from several perspectives. According to Wahab (2005:63) "policy implementation can be seen from the point of view of (1) policy makers, (2) implementing officials in the field, and (3) policy targets (target group)". The main concern of policy makers according to Wahab (2005:63) focuses on "the extent to which the policy has been achieved and what are the reasons that led to the success or failure of the policy". From the implementor's point of view, according to Wahab (2005:64) implementation will focus on "the actions of officials and agencies in the field to achieve program success". Meanwhile, from the point of view of target groups, according to Wahab (2005:64) implementation will be more focused on "whether the implementation of the policy really changes their lifestyle and has a long positive impact on improving the quality of life, including their income".

It should be realized that implementing a policy does not always run smoothly. Many factors can affect the success of a policy implementation.

According to George Edward III in Widodo (2010: 96) there are 4 factors that influence the success or failure of policy implementation, including (1) communication, (2) resources, (3) disposition and (4) bureaucratic structure.

Figure 1.

\section{Determinants of Successful Implementation according to Edward III}

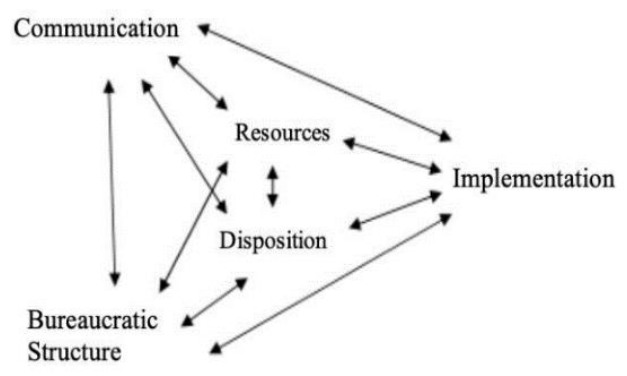

Customer satisfaction on service, service performance and service quality are interrelated with one another. Service quality will determine how much customer satisfaction and reflect the performance of the service. Goetsch and Davis (Fandy Tjiptono and Anastasia Diana 2003: 4), mention quality is "a dynamic condition associated with products, services, people, processes, and the environment that meet or exceed expectations. The concept of quality includes efforts to meet customer expectations, including products, services, people, 
processes and the environment. In addition, quality is a condition that is always changing, for example, what is considered quality today may be considered less quality in the future". Meanwhile, Vincent Gaspersz (2011: 6) states that: There are two definitions of quality, namely conventional and strategic definitions. The conventional definition of quality describes the slim characteristics of a product such as performance, reliability, ease of use, aesthetics, and so on. While the definition of quality in terms of strategic is everything that is able to meet customer needs (meeting the needs of costumeers).

In administering a PATEN there is a substantive requirement, namely the delegation of part of the authority of the regent/mayor to the camat. The delegation of part of the authority of the regent/mayor is carried out so that the efficiency and effectiveness of the service delivery is achieved. The implementation of this PATEN includes licensing and nonlicensing services. The PATENT service standards include:
a. Kind of service
b. Service requirements
c. Service process/procedure
d. The official responsible for the service
e. Service time
f. Service fee

As part of efforts to improve the quality of public services, especially the type of administrative services, PATEN adheres to the principles of public services in accordance with Law Number 25 of 2009 concerning Public Services. These principles are:

a. Public interest, which means that the provision of services by PATEN implementing officers may not prioritize personal or group interests.

b. Legal certainty means that there is a guarantee for the realization of rights and obligations between service recipients (citizens) and service providers (districts) in the administration of PATEN.

c. Equality of rights means that the provision of services in PATEN does not discriminate against ethnicity, race, religion, class, gender, and economic status.

$\mathrm{d}$. The balance of rights and obligations means that the fulfillment of these rights must be proportional to the obligations that must be carried out, both by the provider and the recipient of the service. 
e. Professionalism means that every PATEN implementer must have competence in accordance with his/her field of work.

f. Participatory means increasing community participation in the administration of PATEN by taking into account the aspirations, needs, and expectations of the community.

g. Equality of treatment/non-discrimination means that in the administration of PATEN, every citizen has the right to receive fair services.

h. Openness means that each recipient of the service can easily access and obtain information about PATEN.

i. Accountability means that the process of administering a PATEN must be accountable in accordance with the laws and regulations.

j. Facilities and legal treatment for vulnerable groups means that there are facilities for vulnerable groups so as to create justice in services.

k. Timeliness means that the completion of each type of service that is managed is carried out on time in accordance with the PATEN service standard.

1. Speed, convenience, and affordability mean that every type of service in PATEN is carried out in a precise, easy, and affordable manner by the community receiving the service.

One study that is in line with this is that conducted by (Ananda Gayatri et al., 2021) who found that in carrying out general government tasks such as recording and archiving files in the Sumbawa sub-district office, there is still a large book that is still difficult for staff in the integrated district administration or commonly known as PATEN and will be traced large enough to prevent damage and data loss. 
Table 1.

\section{Difference between Conventional Services and PATEN}

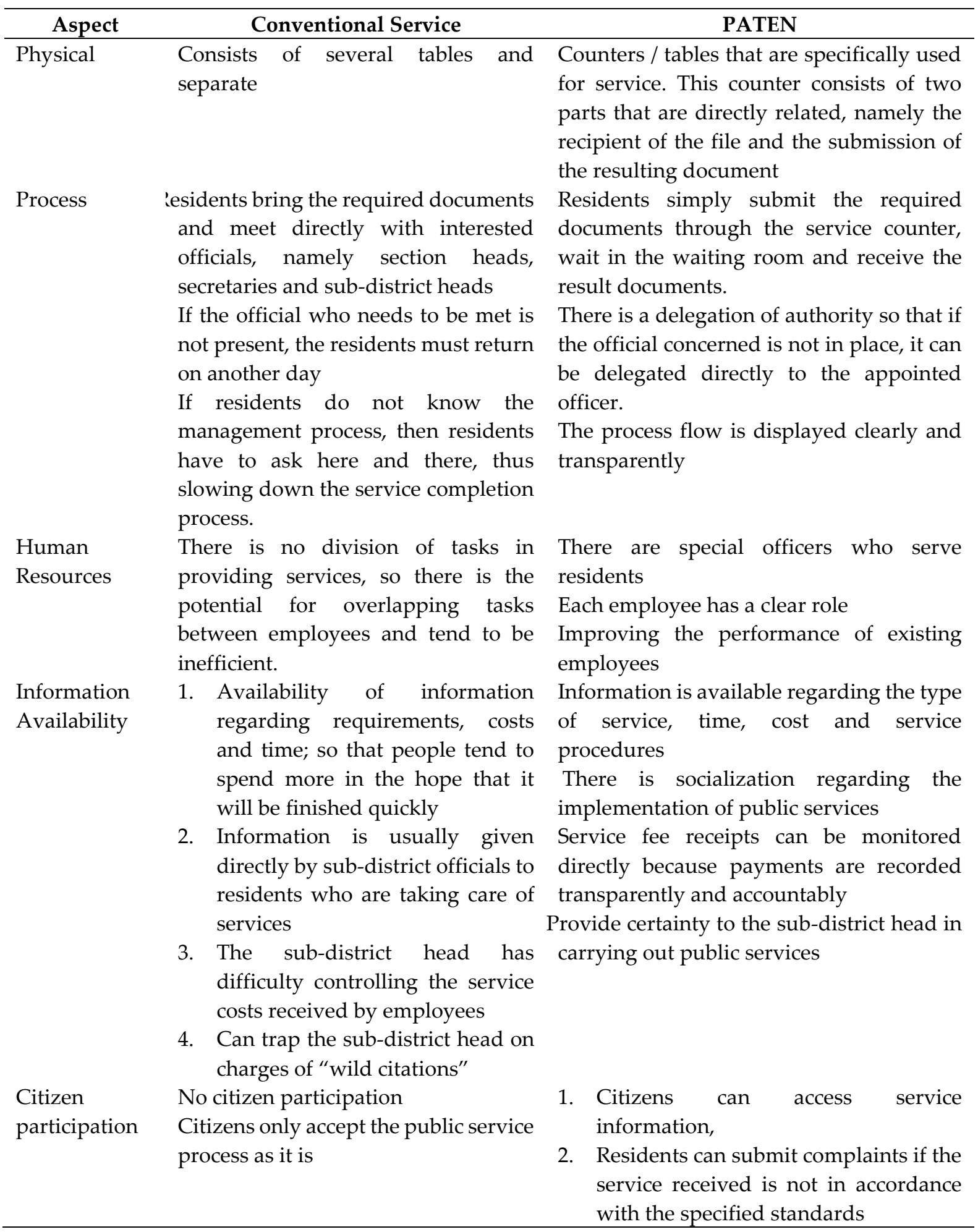

The practice journey of the One Stop Integrated Service (PTSP) in Indonesia is one manifestation of the factual problem of the complexity of integrating various aspects that affect the quality of service. Especially focusing on the phenomenon of additional costs that 
must be borne by the community when reaching and getting services at PTSP which are located in district, city and provincial government centers in Indonesia. Therefore, the theoretical prescriptions referred to still refer to the "traditionality" conception of the gaps model of service quality by Parasuraman, Zeithaml \& Berry (1985, 1988 and 1994).

According to the concept of 'gaps model of service quality', the development of service quality is influenced by four quality factors which, if ignored, have the potential to create service problems. The four factors that should be addressed are: (1) The service provider must be able to understand well the public's expectations of the desired service; minimal attention to this factor will create a management perception gap; (2) Pouring the results of the identification of the community's expectations into service quality specifications, which in practice are commonly equated with service SOPs; if you don't carry out this step properly, it will create a gap in service quality specifications; (3) The provision of services must be as accurate as possible in accordance with the service SOP; otherwise, it will create a service delivery gap; and (4) the promise of service to the community must be reliable, able to be fulfilled in order to avoid the emergence of a marketing communication gap (Parasuraman, Zeithaml \& Berry: 1985, 1988 and 1994). In these four factors, various kinds of public complaints related to the services they receive are sourced. (5) Information regarding the gaps that arise through each of these factors is then reviewed through a survey which will provide an overview of the difference between the perception of customer experience on the service received and the service expected.

Chronologically, according to (Hasan et al., 2019) the dimensions of the hypothetical model of the "Super Service Delivery" concept consist of: (1) Cohabitation of integrative service functions; and (2) Approaching the customer corpus.

The indicators of cohabitation of the integrative service function consist of; (1) Service packages that have been integrated under one roof are provided again through the front line office network; (2) The service is delivered through the leading government network dealing with the community; (3) Front line office services are managed and operated by integrative service personnel; (4) The role of front line office personnel may include recording and transaction services.

Meanwhile, indicators of public services approaching the customer corpus consist of; (1) Integrative services can be received through the leading government network dealing with 
the community; (2) Approaching services so that they are closer to the customer community; (3) Public services that cover the gap in non-service costs.

\section{Methods}

This study is a qualitative descriptive study that emphasizes data in the form of words, pictures, and not numbers caused by the application of qualitative methods. In addition, all that is collected is likely to be the key to what has been researched. This research was conducted in Polewali Mandar Regency which focused on the Analysis of Improved Quality of District Integrated Administration Services (PATEN) in Polewali District, Polewali Mandar Regency. Determination of an informant considers the role and responsibilities of the informant in his position during the interview. Furthermore, based on the data or information obtained from the previous sample, the researcher can determine other samples that are considered to provide more complete data. The informants in this study are: the sub-district head, the sub-district secretary, the service counter staff, and the public or service users.

\section{Results and Discussion}

\section{Results}

\section{Implementation of sub-district integrated services (PATEN) in Polewali sub-district}

Based on the Minister of Home Affairs Regulation Number 4 of 2010 concerning Guidelines for Integrated District Administration Services (PATEN), PATEN is to improve quality and bring services closer to the community. Public services are basically all activities in the context of fulfilling basic needs in accordance with the basic rights of every citizen and resident of an item, service and or administrative service provided by service providers related to the public interest.

District Integrated Administrative Services abbreviated as PATEN is the implementation of Public Services in the District from the application stage to the issuance of documents in one place. As a service center, in the sense that in the future the sub-district is expected to be able to provide services to the community proportionally based on the criteria and scale of the sub-district in the field of licensing and non-licensing. The implementation of the sub-district integrated service policy (PATEN) at the Polewali sub-district office, Polewali Mandar district has been implemented since 2013. Polewali Mandar Regent Regulation 
Number 40 of 2012 concerning Delegation of Part of the Regent's Authority to the Camat within the Polewali Mandar Regency Government. This PATEN policy is also regulated in the decision of the Polewali Mandar Regent Number: KPTS/138/15/HUK concerning the Designation of Polewali District as the Provider of Integrated District Administration Services within the Polewali Mandar District Government.

\section{A. Communication}

In this study, it is focused on the Implementation of the Integrated Administrative Service Policy in Polewali District related to the communication carried out. PATEN is a public service in the field of licensing and non-licensing. With this PATEN, it is hoped that it will be able to provide the best possible service to the community. The delegation of part of the authority which is one of the requirements for implementing a PATEN must be fulfilled by the region in order to support the successful implementation of the Subdistrict Integrated Administrative Services (PATEN) policy. Based on the results of observations made by researchers, since PATEN was implemented in 2013, there have been several positive changes, including making it easier for the community in terms of managing administrative issues in the sub-district and providing excellent service to the community, every employee in the subdistrict must also understand and be responsible for their duties each in terms of the administration of PATENTS.

\section{B. Resources}

Edward III in Widodo (2010: 98) suggests that the resource factor has an important role in policy implementation. According to Edward III in Widodo (2010: 98) that these resources include human resources, budget resources, and equipment resources and authority resources.

The completeness of the facilities at the sub-district office is considered complete, even though during the pandemic, the procedures in the service have changed in terms of file management, because for file management services the sub-district government delivers files. These additional tasks overwhelm service providers due to limited means of transportation.

This is in line with Edward III's theory in Widodo (2010:102) which states that equipment resources are the means used for the operationalization of the implementation of a policy which includes buildings, land, and facilities, all of which will make it easier to provide services in policy implementation. 
The budget resources for implementing the policy are sourced from the Annual Budget Draft in the District and then taken from the District Revenue and Expenditure Budget. This is in line with the theory of Edward III in Widodo (2010: 100) which states in the conclusion of his study "budgetary limitation, and citizen opposition limit the acquisition of adequate facilities. This is turn limit the quality of service that implementors can provide to the public". According to Edward III, the limited available budget causes the quality of services that should be provided to the community is also limited.

\section{Disposition}

The definition of disposition according to Edward III in Widodo (2010:104) is said to be "the willingness, desire and tendency of policy actors to carry out the policy seriously so that what is the policy goal can be realized".

Position determination in the appointment of PATEN officers is determined by the sub-district head and then discussed with the subdistrict secretary and other officials in a meeting. After obtaining an agreement through the meeting, then a Decision Letter is made. This is in line with Edward III's theory of bureaucratic appointments. The disposition or attitude of the implementers will create real obstacles to policy implementation if the existing personnel do not implement the policies desired by officials at a higher structural level. Therefore, the appointment and selection of policy implementing personnel must be people who are dedicated to the policies that have been set, more specifically to the interests of the community.

The role of the government in this regard is considered to be very large, ranging from providing an annual budget for sub-districts to supervising and giving full responsibility for managing the PATEN program. This is in line with Edward III's theory regarding incentives that incentives are one of the recommended techniques to overcome the attitude problem of policy implementers by manipulating incentives. Basically people move based on their own interests, then manipulate incentives by policy makers to influence the actions of policy implementers. By increasing certain profits or costs, it may be a driving factor that makes the implementers carry out orders well. This is done as an effort to fulfill personal or organizational interests. 


\section{Bureaucratic Structure}

Edward III in Widodo (2010:106) states that "policy implementation may still be ineffective because of the inefficiency of the bureaucratic structure". This bureaucratic structure according to Edward III in Widodo (2010:106) includes aspects such as bureaucratic structure, division of authority, relationships between organizational units and so on.

The organizational structure of PATEN, in this case the Camat as the decision maker, was previously a General Functional Service Officer/JFU who was in charge of receiving data/receipts of community reports, then the Head of the relevant subdivision drafted a data report or community file. Furthermore, the Head of the relevant Section verifies the draft file that has been prepared by the Head of the relevant Sub-section. The Camat Secretary receives and initials the File Verification Report, then the Camat signs the file that has been initialed by the Secretary, and JFU sends, Resubmits and archives the data/file report. This is in line with Edward III's research in Winarno (2005:152) which explains that: Standard Operating Procedures (SoP) are very likely to be an obstacle for the implementation of new policies that require new ways of working or new types of personnel to implement new policies. policy. Thus, the greater the need for policy changes in the usual ways in an organization, the greater the probability that the SoP will hinder implementation.

The division of authority and responsibility of the patent service apparatus, in this case the JFU service officer, receives the data/file of the community report, then, the relevant Head of Sub-section compiles a draft of the data report or community file, then the Head of the relevant Section verifies the file drafted by the Head of the relevant Sub-Division, the Secretary of the Camat receives and initials the File Verification Report, then the Camat signs the file that has been Paprafed by the Secretary of State, and the JFU sends, then resubmits and archives the data/file report.

This is in line with Edward III's theory in Widodo (2010:107) which states that: as well as whether or not operating standards are clear, both regarding mechanisms, systems and procedures for implementing policies, division of main tasks, functions and authorities, and responsibilities among actors, and the inharmonious relationship between implementing organizations with one another also determines the success of policy implementation. 


\section{Obstacles in the implementation of District Integrated Administrative Services (PATEN) in Polewali District.}

The Polewali sub-district office as the agency that organizes the sub-district Integrated Administrative Services (PATEN) program must convey information to the public regarding the objectives of the Patent so that the goals and objectives can be achieved optimally.

To find out the obstacles in implementing integrated sub-district administrative services in this study, the approach proposed by Edward III was: 1) Communication; 2) Resources; 3) Disposition; and 4) Bureaucratic structure, for more details can be described as follows:

\section{A. Communication}

Communication Edwar III in Widodo (2010: 97) communication is defined as the process of delivering communicator information to the communicant "information about public policy according to Edward III means that it needs to be conveyed to policy actors regarding what they need to prepare and do to carry out the policy so that the goals and objectives of the policy can be achieved as expected.

The implementation of patent services is considered to be running, both because the community is facilitated and it is not complicated, but when faced with conditions during the covid 19 pandemic, the sub-district patent program issued a regulation regarding file transfers and pick-ups, but this was not supported by the availability of supporting transportation so that the service process Patents in the management of administrative settlements for the public are limited.

The implementation of patent services is considered not to be going well because of the limited provision of patent services to the community during the covid 19 pandemic. What the sub-districts have done is to issue regulations regarding file transfers and pick-ups, but there are transportation constraints in the process. Likewise, the obstacles faced by officers regarding communication in the implementation of the patent service procedure, such as when the complementary files in the issuance of documents are incomplete. This indicates that there are still some people who do not understand this Patent Program.

a. Resource

Edward III stated that the resource factor has an important role in policy implementation according to that these resources include human resources, budgetary 
resources and equipment resources as well as authority resources. related to resources, it is still not running optimally, this is evidenced by the obstacles found in the implementation of patents from the aspect of budget resources and equipment resources, namely the need to fulfill additional welfare costs for patent officers and the lack of supporting transportation for maximum PATENT services.

b. Disposition

The definition of disposition according to Edward III is said to be the willingness, desire and tendency of policy actors to carry out the policy seriously so that what is the goal of the policy can be realized, if policy implementation wants to run effectively and efficiently, the implementers do not only know what to do and have the ability to carry out the policy but they must have the will to implement the policy, but they must also have the will to carry out the disposition in implementing the policy consisting of the appointment of the bureaucracy and incentives. There is a need for clearer monitoring standards related to the use and supervision of budgets by districts so that achievements and obstacles can be evaluated on a regular basis.

c. Beaureaucratic Structure

Ripley and Fraklin in Winarno (2005:149-160) identified six characteristics of bureaucracy as a result of observing the bureaucracy in the United States, namely:

1. Bureaucracy was created as an instrument in dealing with public needs

2. Bureaucracy is the dominant institution in the implementation of public policy which has different interests in its hierarchy

3. Bureaucracy has a number of different purposes.

4. The function of the bureaucracy is in a complex and broad environment

5. Bureaucracy has a high survival instinct with so rarely found dead bureaucracy,

Edward III stated that implementation may still be ineffective due to the inefficiency of the bureaucratic structure including Standard Operating Procedures and fragmentation. Standard Operational Procedure is a development of internal demands for certainty of time and resources as well as the need for uniformity and a complex and extensive work organization. In this regard, the implementation of patent administration must be ensured to run well. 
Based on the results of the interview with SW, it was stated that: the sub-district head as the decision maker, previously the JFU service officer Received the data/files of the community report, then the head of the related sub-section compiled a draft of the data report or community file, then the head of the relevant section verified the files drafted by the subsection head related, the Secretary of the Camat Receives and initials the Report on the Verification of Files, then the Camat Signs the File that has been initialed by the Secretariat, and JFU sends, Returns and archives the report data / Files. With these several stages, it is enough to make it easier for the community but still needs evaluation in order to cut bureaucratic time which is not long.

Based on the results of the interview, it can be concluded that there is a need for a better SOP so that the service process needed can be more concise than now, this is very important for achieving the goals of the PATEN Program, because a successful strategy implementation requires relevant information traffic and also which includes all parts of the organization, the intended service implementation strategy means that the service does not only require all participants to have to understand the strategy and standard operational procedures, but they must also be able to develop the knowledge and skills to implement the strategy and Standard Operational Procedure (SOP) successfully.

\section{Discussion}

Implementation of the Smart Government policy in the Soppeng Regency Government in terms of the system approach has been quite good. From the research results that have been described above, it can be described the discussion of the results of research on the Implementation of PATEN Policy in Polewali District, Polewali Regency along with the obstacles faced can be described as follows;

\section{Communication}

Communication Edwar III in Widodo (2010: 97) communication is defined as the process of delivering communicator information to the communicant "information about public policy according to Edward III means that it needs to be conveyed to policy actors regarding what they need to prepare and do to carry out the policy so that the goals and objectives of the policy can be achieved as expected. 
The understanding of the patent implementer regarding communication in this case is considered to follow the PATEN implementation instructions, and the sub-district has provided training on duties in providing PATEN services.

The obstacles faced in communication on the implementation of patent services are considered not to be going well because of the limitations of providing patent services to the community during the covid 19 pandemic, things that are done by the sub-district are issuing regulations regarding file transfers and pick-ups, but there are transportation constraints in the process as well as obstacles faced by officers regarding communication in the implementation of the patent service procedure, such as when the complementary files in the issuance of documents are incomplete, this indicates that there are still some people who do not understand this Patent Program.

\section{Resources}

Edward III stated that the resource factor has an important role in policy implementation according to that these resources include human resources, budgetary resources and equipment resources as well as authority resources.

The resources related to the facilities in question which are completeness related to the facilities at the sub-district office are considered complete, even though during the pandemic the procedures in the service changed in terms of file management, because for file management services the sub-district government delivered files, therefore we lacked transportation.

In terms of the ability of the apparatus in providing patent services, it is considered quite good, before being assigned at the counter we provide understanding through training plus the available SOPs and the source of the budget for implementing policies obtained from the Annual Budget Draft in the District and then taken from the Regency APBD.

However, there are obstacles related to resources that are still not running optimally, this is evidenced by the existence of obstacles found in the implementation of patents from the aspect of budget resources and equipment resources, namely the need to fulfill additional welfare costs for patent officers and the lack of supporting transportation for maximum service PATENT. 


\section{Disposition}

The definition of disposition according to Edward III is said to be the willingness, desire and tendency of policy actors to carry out the policy seriously so that what is the goal of the policy can be realized, if policy implementation wants to run effectively and efficiently, the implementers do not only know what to do and have the ability to carry out the policy.

The disposition in question is related to determining the position in the appointment of PATEN officers determined by the sub-district head and then discussing it with the secretariat and other officials in a meeting after which a decree is made. Likewise, the government's role in this matter is considered very large, starting from providing an annual budget for sub-districts to supervising and giving full responsibility for managing patents.

The obstacles faced are related to disposition, in this case the need for clearer supervision standards regarding the use and supervision of the budget by the district so that achievements and obstacles can be evaluated on a regular basis.

\section{Bureaucratic Structure}

Edward III stated that implementation may still be ineffective due to the inefficiency of the bureaucratic structure including Standard Operating Procedures and fragmentation. Standard Operational Procedure is a development of internal demands for certainty of time and resources as well as the need for uniformity and a complex and extensive work organization. In this regard, the implementation of patent administration must be ensured to run well.

PATEN organizational structure in this case the Camat as the decision maker, previously the JFU service officer Received the Community report data/file, then, the Head of the relevant Sub-section compiles a draft of the data report or Community File, then the Head of the relevant Section. Secretary of the Camat Receives and initials the Report on the Verification of Files, then the Camat Signs the File that has been initialed by the Secretary of State, and JFU sends, Submits Back and archives the report data / Files.

The obstacles faced related to SOPs are the need for better SOPs so that the service process needed can be more concise than now, this is very important for achieving the goals of the PATEN Program, because a successful strategy implementation requires relevant information traffic and also which includes all parts of the organization, the intended service implementation strategy means that the service does not only require all participants to have 
to understand the strategy and standard operational procedures, but they must also be able to develop the knowledge and skills to implement the strategy and Standard Operational Procedure (SOP) successfully.

\section{Conclusion}

Based on the results of the description above, it can be concluded about the implementation of the PATEN Policy in Polewali District, Polewali Regency and the obstacles faced.

\section{Communication}

The understanding of the patent implementer regarding communication in this case is considered to follow the PATEN implementation instructions, and the sub-district has provided training on the duties of providing PATEN services. Barriers encountered in the communication of the implementation of patent services are considered not to be going well due to the limitations of providing patent services to the public during the COVID-19 pandemic.

\section{Resources}

Resources related to facilities, budget resources and the ability of the apparatus at the early stage are running well, although there are obstacles related to resources that are still not running optimally, this is evidenced by the obstacles found in the implementation of patents from the aspect of budget resources and equipment resources, namely the need for fulfillment of additional welfare costs for patent officers as well as the lack of supporting transportation for maximum patent services.

\section{Disposition}

The role of the government in this regard is considered to be very large, starting from providing an annual budget for the sub-districts to supervising and giving full responsibility for managing patents. The obstacles faced are related to disposition, in this case the need for clearer supervision standards regarding the use and supervision of the budget by the district so that achievements and obstacles can be evaluated on a regular basis.

\section{Bureaucratic Structure}

The bureaucratic structure in this case is considered very procedural to the most technical part. The obstacles faced related to SOPs are the need for a better SOP so that the 
service process needed can be more concise than now, this is very important for achieving the goals of the PATEN Program

\section{References}

Ananda Gayatri, N., Nawassyarif, Ismiyarti, W., Khair, S., \& Muti'ah. (2021). Sistem Informasi Pendataan Dan Pengarsipan Berkas Pelayanan Administrasi Terpadu Kecamatan (Paten) Di Kecamatan Sumbawa Dengan Metode Waterfall. Jurnal Informatika, Teknologi Dan Sains, 3(1). https://doi.org/10.51401/jinteks.v3i1.983

Caiden, G. E. (1991). What Really Is Public Maladministration? Public Administration Review, 51(6). https://doi.org/10.2307/976599

Hasan, I. R., Agustang, A., Kahar, F., \& Tahir, H. (2019). "Super Service Delivery": An advanced conceptual model of one-stop service for wide administrative region. Problems and Perspectives in Management. https://doi.org/10.21511/ppm.17(1).2019.17

Kementerian Pendayagunaan Aparatur Negara Republik Indonesia. (2003). Keputusan Pendayagunaan Aparatur Negara Nomor : 63/KEP/M.PAN/7/2003 Tentang Pedoman Umum Penyelenggaraan Pelayanan Publik (p. 21).

Kepmendagri. (2017). Berita Negara. Menteri Kesehatan Republik Indonesia Peraturan Menteri Kesehatan Republik Indonesia, Nomor 65(879), 2004-2006. https://doi.org/10.1093/bioinformatics/btk045

Keputusan Bupati Polewali mandar. (2013). Bupati polewali mandar. 19-20.

Menpan. (2010). Peraturan Mentri Dalam Negeri Nomor 4 Tahun 2010 Tentang Pedoman Pelayanan Administrasi Terpadu Kecamatan. 45, 39.

Pemerintah, P. (2008). Peraturan pemerintah Republik Indonesia Nomor 19 tahun 2008 tentang Kecamatan. Peraturan Pemerintah.

Perbub No 10. (2013). Bupati polewali mandar.

Presiden, R. (2015). Undang-Undang RI No 9 tahun 2015 tentang Perubahan Kedua atas UndangUndang no 23 tahun 2014 tentang Pemerintah Daerah. 1-14. https://doi.org/10.1016/S00219800(68)80014-6

Undang-Undang No. 23 Tahun 2014 tentang Pemerintahan Daerah. (2014). No Titleر. Peraturan Pemerintah, 8(33), 44. 